\title{
偏析法による溶融アルミニウムの高純度化に 関する基礎研究
}

\author{
嶋影 和宜* · 山本 裕司** \\ 玉井 京子** . 江島 辰彦***
}

\section{Fundamental studies on the purification of}

liquid aluminum by segregation process

\author{
Kazuyoshi SHIMAKAGE*, Yuji YAMAMOTO** \\ Kyoko TAMAI** and Tatsuhiko EJIMA***
}

The purification behaviors of liquid aluminiums containing impurity elements have been investigated by means of segregation process which utilizes segregation phenomena of solute in the solidification of liquid metal. After liquid aluminium was unidirectionally solidified under the conditions of ultrasonic vibration and mechanical stirring, the distribution of impurity concentration was examined against the solidified length. Copper, Magnesium and iron in liquid aluminium were used as impurity elements. The experimental results obtained are summarized as follows:

(1) For each aluminium alloy, the distribution of impurity concentration after the solidification was dependent on initial impurity concentration in liquid aluminium. These behaviors could be explained by the variation of the shape in the solid-liquid interface which is presumed by constitutional supercooled theory.

(2) When aluminium alloys containing low impurity were solidified with the conditions of ultrasonic vibration and mechanical stirring, the purification of aluminium alloys proceeded in accordance with theoretical solidified curve.

(3) The effects of ultrasonic vibration and mechanical stirring on the purification of aluminium alloys having the concentration of high impurity were larger than those of aluminium alloys containing low impurity. These results may suggest that the solid-liquid interface during the solidification is fully mixed with ultrasonic vibration and mechanical stirring and impurity elements escaped from the solid transfers easily to bulk layer in melt.

Keywords: purification, liquid aluminum, segregation process, unidirectional solidification, ultrasonic vibration, mechanical stirring

(Received August 25, 1986)

\section{1. 緒言}

近年, わが国においては電子機器産業, 情報処理産業 などの新分野の産業が著しい発展を遂げているが，これ らの分野においては従来の実用金属の中で不純物含有量 の少ない高純度の金属の需要が要求されている。金属ア ルミニウムにおいてもその例にもれず，磁気メモリーデ ィスク基板, 電解コンデンサー䈃, 超電導線安定化材,
自動車部品, 熱交換器などの用途のために高純度のアル ミニウムの利用が増加する傾向にある1)。現在高純度ア ルミニウムは三層式電解法によつて主に生産されている が，その製造コストは一次地金の製造費よりも高く、そ の上電力費の高騰が製品価格に反映するため，電解製精 とは異つた新しい精製法の開発が要求されている。 そこで本研究においては溶融金属を凝固した場合の溶 質の偏析現象 $\left.{ }^{2}\right)$ 着目し，アルミニウムの精製法とし

* 室蘭工業大学工学部 (室蘭市)。Faculty of Engineering, Muroran Institute of Technology (Muroran).

** 東北大学大学院 (仙台市)。Graduate School, University of Tohoku (Sendai).

*** 東北大学工学部 (仙台市)。Faculty of Engineering, University of Tohoku (Sendai). 
て, 不純物を含有したアルミニウムを一度溶融した後, 機械的擋拌と超音波振動を同時に加えながら一方向的に 凝固させ，不純物を最終凝固部に濃縮・除去する基礎研 究を行つた。すなわち一次アルミニウム地金中に不純物 として比較的多く含まれ，また精製工程中で混入する可 能性も大きく, 電解法では除去し難いとされている鉄, 銅，マグネシウムを不純物に選び，これら不純物濃度の 異なる 3 種類の $\mathrm{Al}-\mathrm{Fe}, \mathrm{Al}-\mathrm{Cu}, \mathrm{Al}-\mathrm{Mg}$ の各合金を作製 し, 合金融体に超音波振動および機械的擋汼を加えて種 々の凝固条件下で㠜固させ，不純物濃度による凝固組織

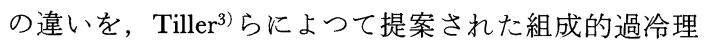
論により推定し, 精製におよぼす凝固組織の影響を考察 するとともに，精製に対する超音波振動および機械的擋 拌の有効性について検討を行つた。本報告はそれらの結 果について報告するものである。

\section{2. 原理}

2 元系合金における固相と液相の平衡は通常状態図で 固相線と液相線の 2 本の線で与えられる。このことは固 相の組成が平衡する液相の組成と異なることを示唆す る。ある一定温度での液相の溶質濃度 $C_{l}$ とそれと平衡 にある固相の溶質濃度 $C_{s}$ との比として表される平衡分 配係数 $k\left(k=C_{s} / C_{l}\right)$ が 1 より小さい 2 元系合金を溶解 し，平らな固液界面が生成する条件で，一端から一方向 凝固を行らと，固相の溶質濃度分布は固相から排出され た溶質が液相のバルクへいかに拡散，流動するかによつ て変化し, 各仮定のもとに固相率に対してFig. 1 の らに表される2,4),5)。Fig. 1 の曲線(1)は固相中の溶質の 拡散は無視できるほど小さく, 液相内には流動がなく, 固相から排出された溶質の移動は拡散のみによつて行わ れる場合で，曲線(2)および(3)は液相中で溶質の完全ある

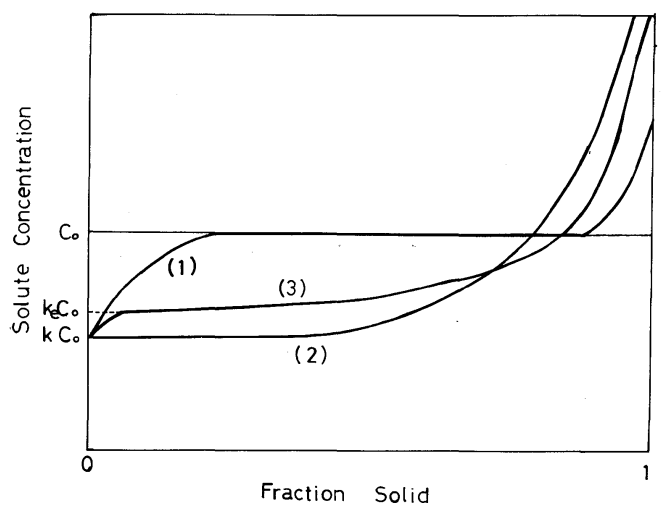

Fig. 1 Solute distribution in unidirectional solidification. (1) Mixing in the liquid is caused by diffusion. (2) Mixing in the liquid is complete. (3) Mixing in the liquid is partial.
いは部分的な混合が行われる場合であり，平衡分配係数 $\mathrm{k}$ 之実効分配係数 ke を用いれば凝固後の固相の溶質濃 度 $C_{s}$ は(1)式と(2)式で与え

$$
\begin{aligned}
& C_{s}=k C_{0}\left(1-f_{s}\right)^{k-1} \\
& C_{s}=k_{e} C_{0}\left(1-f_{s}\right)^{k e-1}
\end{aligned}
$$

られる。ここで $C_{0}$ は初期溶質濃度, $f_{s}$ は固相率で, $k_{e}$ は平衡分配係数を用いて，(3)式から求められる6)。

$$
k_{e}=k /[k+(1-k) \exp (-V \delta / D)]
$$

ここで $V$ は固液界面の進行速度 (凝固速度), $\delta$ は境界 層の厚さ， $D$ は溶質の㧪散係数である。このように排出 された溶質の濃度分布は各条件によつて異なるが，この 偏析現象を利用して溶融アルミニウムの精製を行う場合 には曲線 (3)のように溶質濃度を分布させるのが理想的 である。

そこで本研究では固相から排出された不純物のバルク 相への移動を促進し，液相と充分に混合させるために超 音波振動および機械的擋拌を同時に行らことを考えた。

また前述の溶質の濃度分布は固液界面が凝固方向に垂 直な平滑面として凝固する場合に対応するものである が，セル状あるいはデンドライト状で界面が成長する場 合に注固相から排出された溶質がセ儿壁およびデンドラ イト間隙に捕捉・濃縮され(1)式，(2)式は成立し難くな る。そこで本研究では Tiller ら ${ }^{3}$ とよつて提唱され，平 らな界面の安定性を推定することができる組成的過冷理 論によつて不純物濃度の変化による凝固組織の検討を行 つた*。組成的過冷理論による平らな界面の安定条件は (4)式で与学ることができる。

$$
G \geqq-m C_{0}(1-k) V / k D
$$

ここで $G$ は液相中の温度勾配, $m$ は液相線の温度勾 配， $C_{0}$ は合金組成，Vは凝固速度，D溶融了ルミ= ウム中の不純物元素の拡散保数である。

\section{3. 実験装置および方法}

\section{1 試料}

実験試料は市販の $99.99 \mathrm{wt} \% \mathrm{Al}, 99.9 \mathrm{wt} \% \mathrm{Cu}, \mathrm{Al}-7$ wt $\% \mathrm{Mg}$ 母合金， $99.9 \mathrm{wt} \% \mathrm{Fe}$ をそれぞれ所定の組成に 配合し，高周波溶解炉で溶解して鋳型飞鋳込及，直径 $15 \mathrm{~mm}$, 長さ $65 \mathrm{~mm}$ の丸棒に切削して作製した。これ ら各試料の化学分析結果を Table 1 亿示す。これらの試 料は不純物濃度が高いものと低いものとに分けられる。 実験では各試料とも 60〜65 g 秤量し, 石油ベンジン, エチルアルコールで充分に洗浄後, 実験に使用した。

\section{2 装置}

装置の概略図をFig. 2 亿示す。炬はカンタル線管状

\footnotetext{
*平らな界面をさらに議論するには Mullins ら7〕よ る摂動理論があるが，精製実験であるので簡便な組 成的過冷理論を用いた。
} 
Table 1 Initial solute concentration and solidification conditions of various aluminum alloys

\begin{tabular}{|c|c|c|c|c|c|c|}
\hline Sample & $\mathrm{Cu}$ & $\begin{array}{l}(\mathrm{wt} \% \\
\mathrm{Mg}\end{array}$ & $\mathrm{Fe}$ & $\begin{array}{c}G \\
\left({ }^{\circ} \mathrm{C} \cdot \mathrm{cm}^{-1}\right)\end{array}$ & $\begin{array}{l}R \times 10^{-4} \\
\left(\mathrm{~cm} \cdot \mathrm{sec}^{-1}\right)\end{array}$ & Other conditions \\
\hline No. 1 & 0.012 & - & - & 31.8 & 1.78 & \\
\hline No. 2 & 0.012 & - & - & 35.0 & 1.42 & Ultrasonic vibration \\
\hline No. 3 & 0.012 & - & - & 31.6 & 2.05 & $\begin{array}{l}\text { Ultrasonic vibration } \\
\text { Mechanical stirring }\end{array}$ \\
\hline No. 4 & 0.10 & - & - & 34.3 & 1.65 & \\
\hline No. 5 & 0.10 & - & - & 35.6 & 1.78 & Ultrasonic vibration \\
\hline No. 6 & 0.10 & - & - & 35.3 & 1.64 & $\begin{array}{l}\text { Ultrasonic vibration } \\
\text { Mechanical stirring }\end{array}$ \\
\hline No. 7 & 0.85 & - & - & 36.4 & 1.53 & \\
\hline No. 8 & 0.85 & - & - & 41.2 & 1.61 & Ultrasonic vibration \\
\hline No. 9 & - & - & - & 32.8 & 1.40 & $\begin{array}{l}\text { Ultrasonic vibration } \\
\text { Mechanical stirring }\end{array}$ \\
\hline No. 10 & - & 0.015 & - & 30.3 & 1.99 & \\
\hline No. 11 & - & 0.015 & - & 38.7 & 1.34 & Ultrasonic vibration \\
\hline No. 12 & - & 0.015 & - & 34.0 & 1.64 & $\begin{array}{l}\text { Ultrasonic vibration } \\
\text { Mechanical stirring }\end{array}$ \\
\hline No. 13 & - & 0.14 & - & 35.5 & 1.65 & \\
\hline No. 14 & - & 0.14 & - & 36.4 & 1.51 & Ultrasonic vibration \\
\hline No. 15 & - & 0.14 & - & 37.2 & 1.51 & $\begin{array}{l}\text { Ultrasonic vibration } \\
\text { Mechnical stirring }\end{array}$ \\
\hline No. 16 & - & 2.47 & - & 33.7 & 1.38 & \\
\hline No. 17 & - & 2.47 & - & 33.9 & 1.48 & Ultrasonic vibration \\
\hline No. 18 & - & 2.47 & - & 35.0 & 1.29 & $\begin{array}{l}\text { Ultrasonic vibration } \\
\text { Mechanical stirring }\end{array}$ \\
\hline No. 19 & - & - & 0.013 & 33.9 & 1.31 & \\
\hline No. 20 & - & - & 0.013 & 33.2 & 1.51 & Ultrasonic vibration \\
\hline No. 21 & - & - & 0.013 & 30.7 & 1.54 & $\begin{array}{l}\text { Ultrasonic vibration } \\
\text { Mechanical stirring }\end{array}$ \\
\hline No. 22 & - & - & 0.10 & 33.0 & 1.31 & \\
\hline No. 23 & - & - & 0.10 & 32.4 & 1.28 & Ultrasonic vibration \\
\hline No. 24 & - & - & 0.10 & 35.2 & 1.64 & $\begin{array}{l}\text { Ultrasonic vibration } \\
\text { Mechanical stirring }\end{array}$ \\
\hline No. 25 & - & - & 1.04 & 21.2 & 1.17 & \\
\hline No. 26 & - & - & 1.04 & 29.1 & 1.10 & Ultrasonic vibration \\
\hline No. 27 & - & - & 1.04 & 30.3 & 1.40 & $\begin{array}{l}\text { Ultrasonic vibration } \\
\text { Mechanical stirring }\end{array}$ \\
\hline
\end{tabular}

$G$ : The temperature gradient measured in this study

$R$ : The transfer rate of solidification interface measured in this study

抵抗炬で，大きな温度勾配を得るため 3 段炉とした。炬 の上下方向の移動はシンクロナスモータで行い, 約 6 $\mathrm{mm} / \mathrm{hr}$ の一定速度で作動して, 均一な凝固速度を得る よらにした。試料を入れる黒鉛るつぼの形状は内径 19 $\mathrm{mm}$, 深さ $145 \mathrm{~mm}$, 長さ $155 \mathrm{~mm}$ の試料装入部とその 下部の外径 $20 \mathrm{~mm}$, 長さ $65 \mathrm{~mm}$ のホーン接合部からな り，超音波振動の減衰を少なくするようにした。試料の 温度は黒鉛るつぼ壁にあけた孔にクロメルーアルメル熱 電対を挿入し，アルミナセメントで固定して試料の底, 底から $20 \mathrm{~mm}, 50 \mathrm{~mm}$ および $80 \mathrm{~mm}$ の所で測定した。 超音波発生装置は海上電機社製の多周波超音波発生装置
T-A-4014で，振動子には4202型振動子を用いた。周波 数はすべて $20 \mathrm{kHz}$ で実験を行つた。本実験では大きな 振動振幅を必要とするので, 振動子に振動振幅拡大用の SUS 304 ステンレス鋼製ホーンを接合し，このホーン 先端に黒鉛るつぼをねじ止めして使用した。なお，振動 子，ホーンを一体と考えた振動系はそれぞれが半波長共 振するよらに，その寸法，形状を決定した。溶融アルミ ニウムの擋拌には直径 $6 \mathrm{~mm}$ の SSA-S アルミナ管を使 用し, ユニバーサルジョイントを経て撹拌装置に接続し た。この擋汼棒は凝固界面の移動距離を測定するのにも 用いた。 


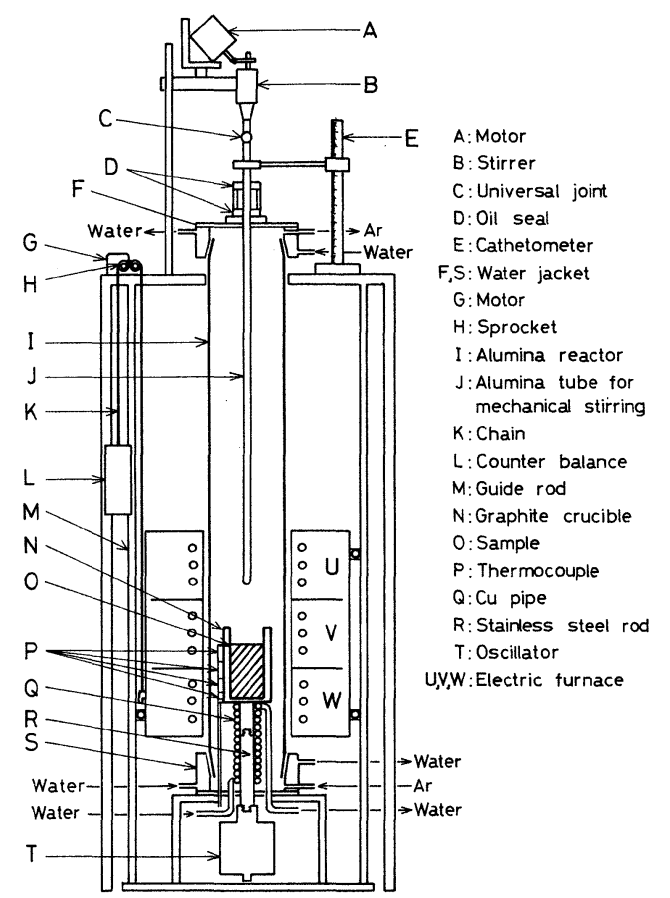

Fig. 2 Purification apparatus for solidification.

\section{3 方 法}

まず，黒鉛るつぼをエチルアルコールで洗浄し，乾燥 後, 試料を装入してホーンをねじ止めする。次に熱電対 を黒鉛るつぼ壁の孔にアルミナセメントで固定し, 反応 管，水冷キャプ，アルミナ管を Fig. 2 のよ5にセット する。反応管内を真空に引いた後アルゴンを充填し, 温 度を上げ，所定の温度に達したら一定時間保持後，洰を 一定速度で引き上げて下から試料を凝固させる。凝固条 件に応じて超音波振動および機械的擋找を行つた。擋拌 挝 48 r.p.m. の回転速度で, 凝固界面上約 $2 \mathrm{~cm}$ の所で 行うよう20分每に調整した。試料の温度は凝固開始後 20 分間隔で熱電対の温度を記録して測定した。また凝固界 面の移動距離は温度測定時にあらかじめ基準線を決めて ある撹拌棒を凝固界面まで下げ，その時の基準線の位置 をカセトメータで読み取り, その差から求めた。実験終 了後, 黒鉛るつぼを装置から取り出し, 試料の分析を行 つた。

分析は凝固距離ごとに試料を採取し，エチルアルコー ルで洗浄した後, JIS 規格に基づく原子吸光光度法8)で 行つた。また， $\mathrm{Al}-0.013 \mathrm{wt} \% \mathrm{Fe}$ 合金試料はセイコー電 子工業社製 SMA $/ 850$ 型状態分析装置を用いて X 線面 分析を行い，不純物の偏析状態を観測した。

\section{4. 実験結果}

各試料の精製前の不純物濃度 $C_{0}$, 凝固過程の温度勾

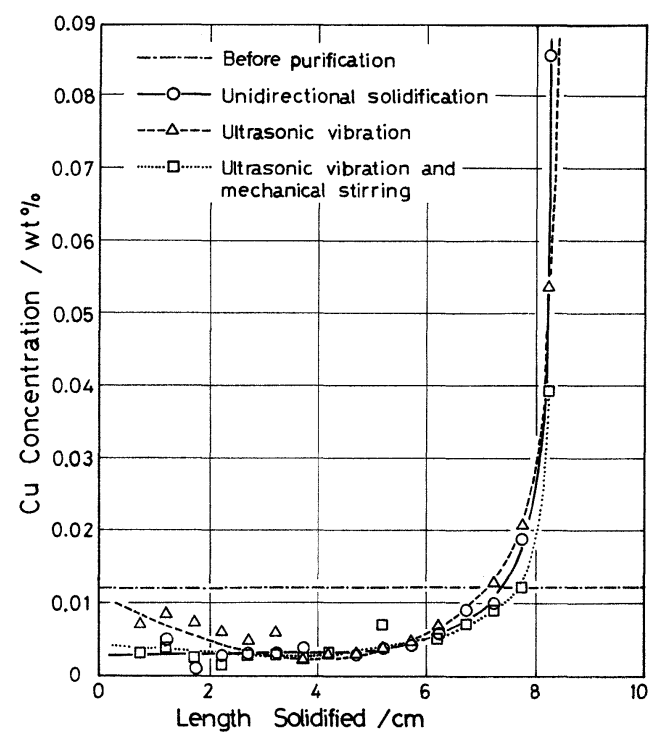

Fig. 3 Relation between $\mathrm{Cu}$ concentration and the solidified length.

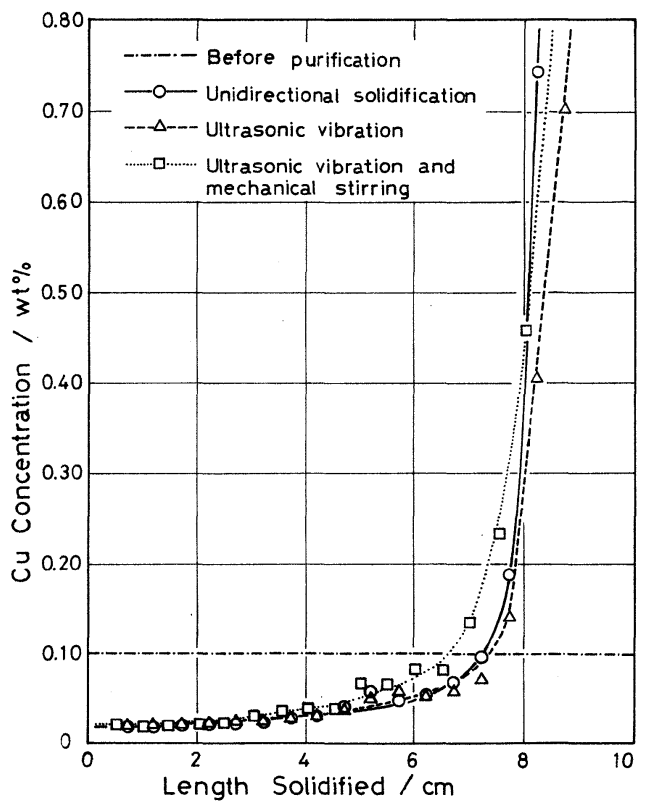

Fig. 4 Relation between $\mathrm{Cu}$ concentration and the solidified length.

配 $G$ および凝固界面の移動速度 $R$ をTable 1 に示す。 ここで $G$ は黒鉛るつぼ壁の孔に装入した各熱電対の温 度差を熱電対間の距離で割つた值であり， $R$ は凝固界面 の移動距離を測定時間で割つて得た平均值である。

\section{$4.1 \mathrm{Al}-\mathrm{Cu}$ 合金の精製}

最初に超音波振動および機械的擋拌の効果を知るため, 


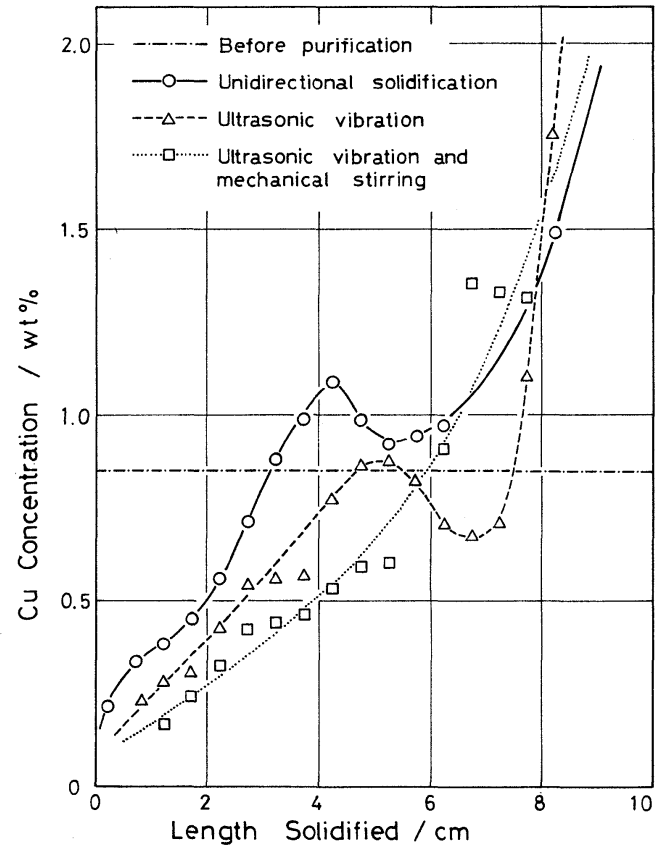

Fig. 5 Relation between $\mathrm{Cu}$ concentration and the solidified length.

$\mathrm{Al}-0.012 \mathrm{wt} \% \mathrm{Cu}$ 合金， $\mathrm{Al}-0.1 \mathrm{wt} \% \mathrm{Cu}$ 合金を用いて一 方向的凝固を行つた場合，凝固の際超音波振動を加えた 場合および，超音波振動と機械的擋汼を同時に与えた場 合と処理条件を変えて実験を行つた。その結果を縦軸に $\mathrm{Cu}$ 濃度，横軸に凝固距離を取り，Fig. 3 および Fig. 4 に示す。図から明らかなようにいずれの凝固の場合も， 最終凝固部に $\mathrm{Cu}$ の濃縮, 偏析が認められ，初期凝固部 で $\mathrm{Cu}$ は精製されていることが分かる。しかし処理条件 によつて精製の度合には著しい差は認められない。そこ で $\mathrm{Al}-0.85 \mathrm{wt} \% \mathrm{Cu}$ 合金を用いて同様な処理条件下で実 験を行つた。得られた結果を Fig. 5 に示す。Cu濃度の 高い $\mathrm{Al}-0.85 \mathrm{wt} \% \mathrm{Cu}$ 合金では $\mathrm{Cu}$ 濃度の低いFig. 3, Fig. 4 の結果と異なり，処理条件の違いによつて Cuの 偏析度合に差が認められ，超音波振動と機械的摚拌を同 時に与えた場合に初期凝固領域で最も精製されているこ とが分かる。また超音波振動を加兄た場合は一方向的に 凝固した場合よりも精製の度合が高く，Cu濃度の低い Fig. 3 および Fig. 4 の結果と挙動が異なる。またこれら の凝固時の $\mathrm{Cu}$ の濃度変化は凝固距離に対し一様な増加 を示していないが，これは凝固過程で凝固組織に変化が あるからではないかと推察されている。しかしその原因 の詳細は不明である。

\section{$4.2 \mathrm{Al}-\mathrm{Mg}$ 合金の精製}

次に $\mathrm{Al}-\mathrm{Mg}$ 合金の精製実験を行つた。 $\mathrm{Al}-0.015 \mathrm{wt} \%$

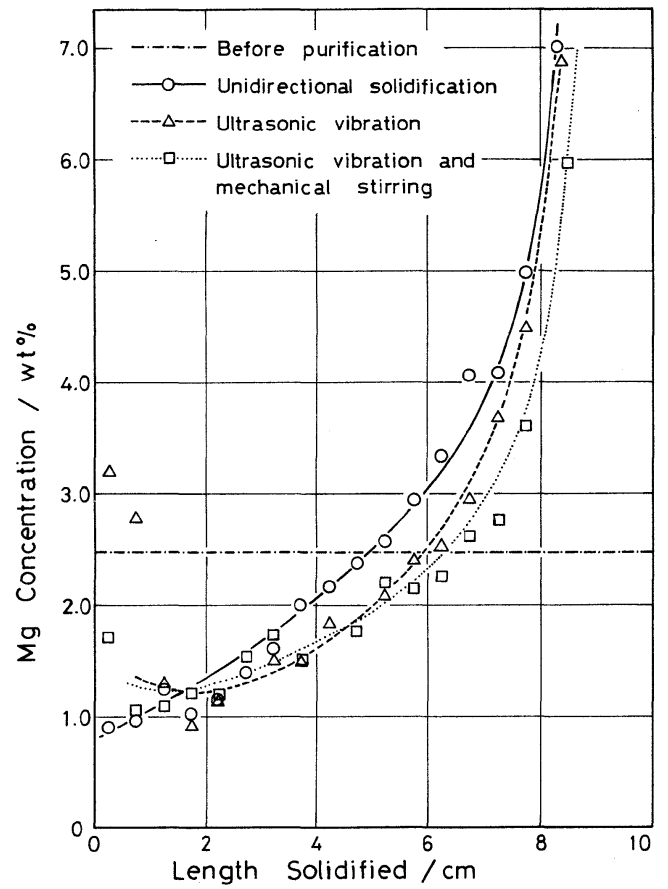

Fig. 6 Relation between $\mathrm{Mg}$ concentration and the solidified length.

$\mathrm{Mg}$ 合金および $\mathrm{Al}-0.14 \mathrm{wt} \% \mathrm{Mg}$ 合金の $\mathrm{Mg}$ 濃度の低い 合金では $\mathrm{Al}-\mathrm{Cu}$ 合金と同梯に処理条件の差によつて $\mathrm{Mg}$ の精製挙動に著しい変化は認められなかつた。そこ で $\mathrm{Mg}$ 濃度の高い $\mathrm{Al}-2.47 \mathrm{wt} \% \mathrm{Mg}$ 合金を用いて実験を 行つた。その結果を Fig. 6 亿示す。眓から分かるよう に $\mathrm{Mg}$ 濃度の低い場合と異なり，この合金の処理では超 音波振動と機械的擋汼を同時に与えて凝固させた場合が 最も精製されており，続いて超音波振動を加えた場合， 一方向的凝固の場合と精製の度合が低下している。この 精製傾向は $\mathrm{Cu}$ 濃度の高い $\mathrm{Al}-0.85 \mathrm{wt} \% \mathrm{Cu}$ 合金の精製 挙動之同様である。また初期凝固部の凝固長さ約 0.2 付 近には $\mathrm{Mg}$ 濃度の高い測定点も認められるが，これは凝 固の初期では界面状態が不安定であること，超音波振動 の伝播が不均一であることなどに起因すると考えられ る。

\section{$4.3 \quad \mathrm{Al}-\mathrm{Fe}$ 合金の精製}

続いて $\mathrm{Al}-\mathrm{Fe}$ 合金試料を用い，処理条件を変えて精 製実験を行つた。 $\mathrm{Al}-0.1$ wt\% Fe 合金の測定結果を Fig. 7 亿示す。眓によれば $\mathrm{Fe}$ 濃度は初期凝固部では初期濃 度よりも著しく低く, 凝固距離の増加とともに, 次第に 増加し，最終凝固領域で極めて高い值を示す。このこと はいずれの処理条件下でも Fe は最終凝固部に濃縮, 偏 析することを示唆する。最終凝固領域における $\mathrm{Fe}$ 偏析 の度合を比較すると超音波振動と機械的摚拌を同時に与 


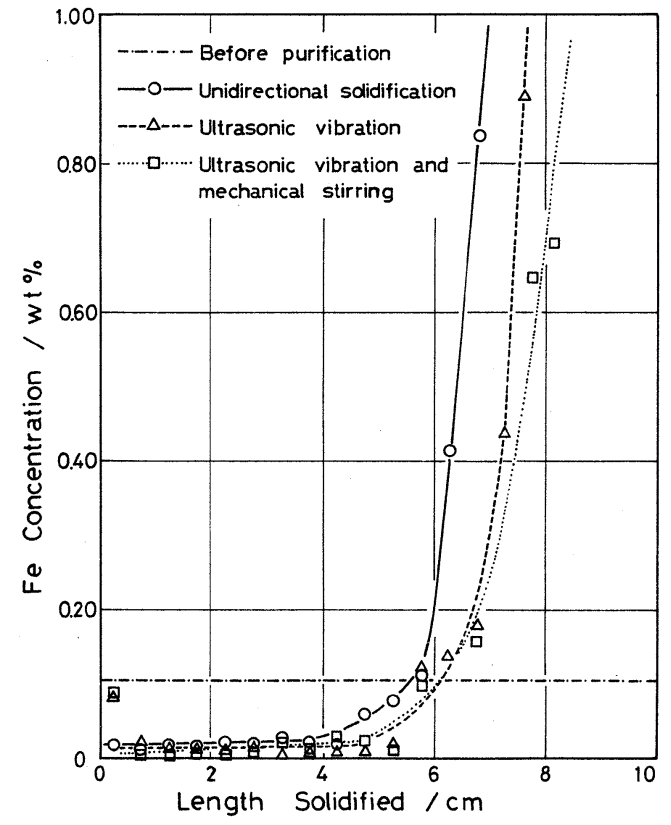

Fig. 7 Relation between Fe concentration and the solidified length.

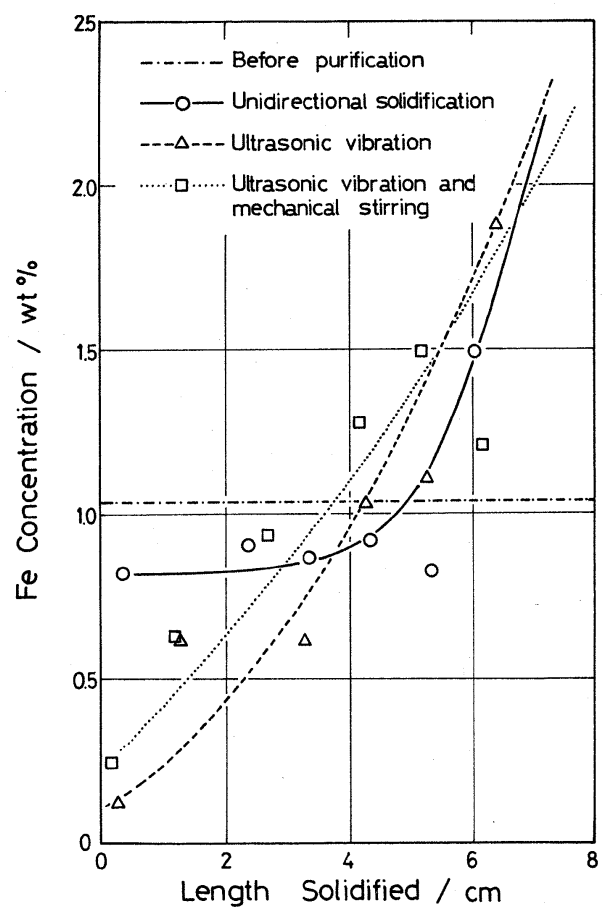

Fig. 8 Relation between Fe concentration and the solidified length.

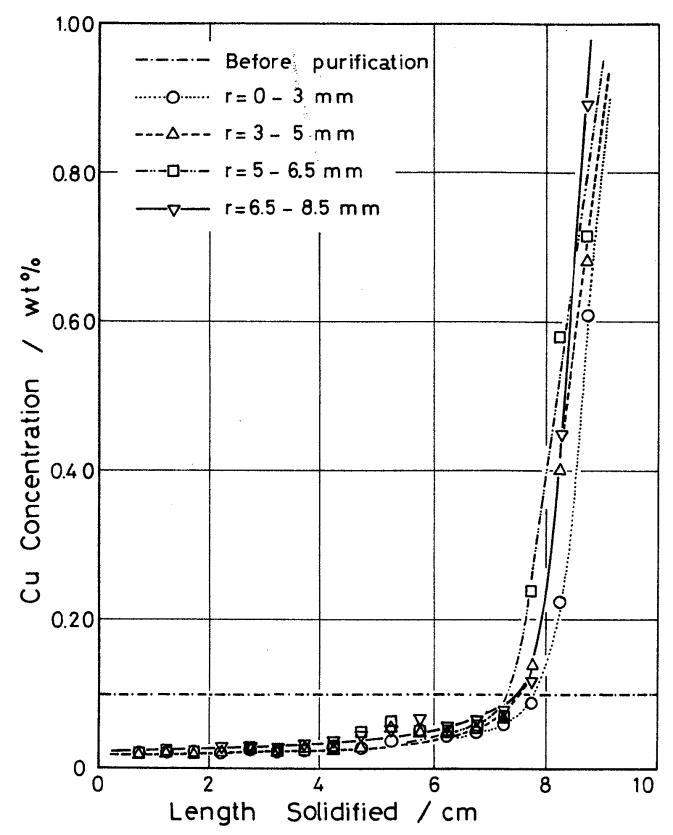

Fig. 9 Radial distribution of $\mathrm{Cu}$ for the solidification with ultrasonic vibration.

えた場合 >超音波振動を与えた場合>一方向的凝固の場 合の順に前者汪ど大きくなる。次に $\mathrm{Al}-1.04 \mathrm{wt} \% \mathrm{Fe}$ 合 金の精製結果をFig. 8 に示す。この合金処理では初期 凝固部の $\mathrm{Fe}$ 濃度は初期濃度より低いが，処理条件によ つて異なつた濃度を示す。この挙動は前述した $\mathrm{Al}-\mathrm{Cu}$ 合金, $\mathrm{Al}-\mathrm{Mg}$ 合金の不純物濃度の高い場合と同様で, 精製の度合が㠜固条件によつて異なることを示してい る。この場合も精製の容易さは超音波振動之機械的摚汼 を同時に加えた場合が最も大きい。

\section{4 凝固垂直方向の不純物濃度分布}

凝固方向の濃度分布と同時に試料垂直方向の不純物濃 度分布を調べ，凝固試料の内側と外側で不純物濃度に差 が認められるかどらかを検討した。代表的例として Al$0.1 \mathrm{wt} \% \mathrm{Cu}$ 合金を用い超音波振動のみを与えた試料の 結果を Fig. 9 亿示す。図中の r は円柱状凝固試料の外 側からの距離を表す。図から分かる上うに, Gu 濃度は 凝固距離約 $7.5 \mathrm{~mm}$ をでは外側からの距離 $\mathrm{r}$ とよつて殆 ど変化せず，各凝固部の濃度差は認められない。しかし $\mathrm{Gu}$ 濃度の偏析が著しく増大する最終凝固領域では $\mathrm{r}=5 \sim 6.5 \mathrm{~mm}, \mathrm{r}=6.5 \sim 8.5 \mathrm{~mm}$ で示される外側の $\mathrm{Cu}$ 濃度が $\mathrm{r}=0 \sim 3 \mathrm{~mm}$ で表される内側の濃度より若干高い 值を示している。しかしこれらの結果から不純物 $\mathrm{Cu}$ の 偏析度合を全体的に判断すると, 凝固垂直方向の濃度分 布は凝固方向の不純物濃度分布之同一であり, 凝固試料 の内側と外側で不純物濃度に差がないことが分かる。 

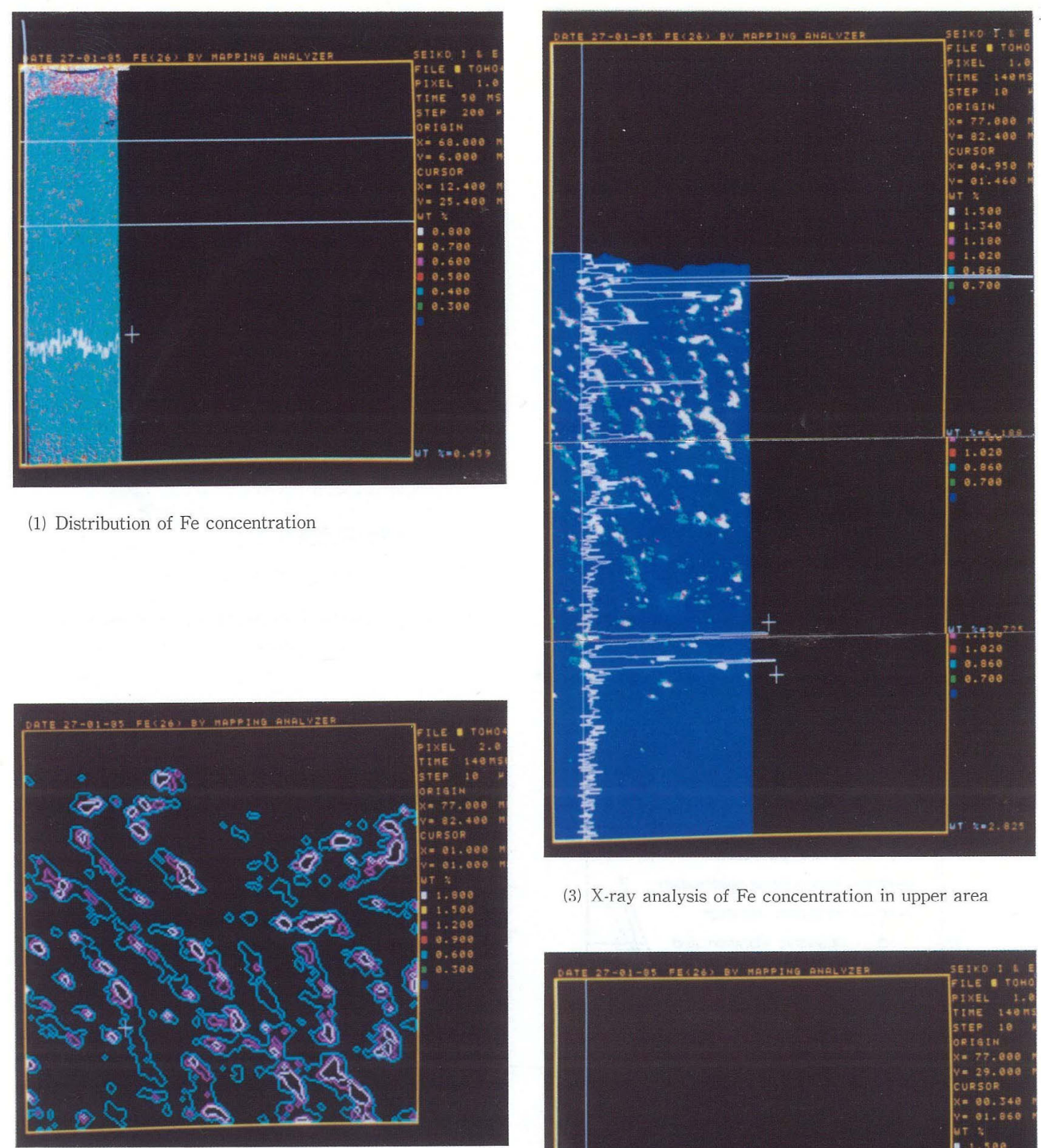

(3) X-ray analysis of Fe concentration in upper area

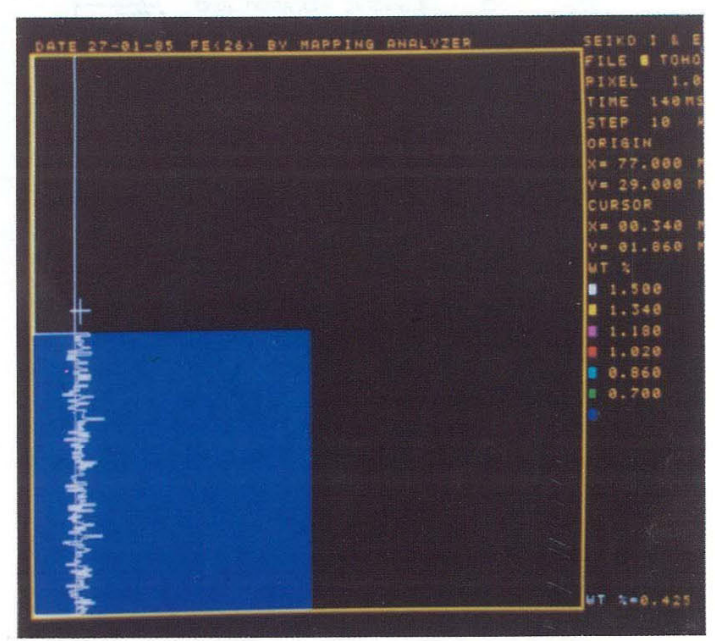

(4) X-ray analysis of Fe concentration in lower area

Fig. 10 Mapping analysis of $\mathrm{Al}-0.013 \mathrm{wt} \% \mathrm{Fe}$ alloy solidified. 
4.5 マッピングアナライザーによる不純物元素の観 察

試料中の元素の分布状態打よび不純物の偏析状態を明 確に識別できるマッピングアナライザーを用いて，本実 験の化学分析による測定結果の妥当性を検討した。凝固 後の試料を綐方向に切断して, その全体の面分析を行つ た。不純物濃度の低い $\mathrm{Al}-0.013 \mathrm{wt} \% \mathrm{Fe}$ 合金の面分析の 結果をFig. 10 亿をとて示す。Fig. 10(1)は一方向的 に凝固を行つた試料の下端から上端までの $\mathrm{Fe}$ 分布状態 を濃度別にカラー表示し, 試料の断面を線分析して示し たものである。写真上部の赤で示されている領域に $\mathrm{Fe}$ が濃縮されており, 試料の下部, 中部領域では $\mathrm{Fe}$ 濃度 が低いことが分る。また線分析によれば試料の外側之内 側で Fe 濃度に差が認められない。Fig. 10(3) および(4) は画像分解能を上げ， $\mathrm{Fe}$ 濃度の分布状態を観測したも のである。Fig. 10(4)の写真は下端から $3 \mathrm{~cm}$ 離れた部 分の $\mathrm{Fe}$ 分布のプロファイルを示すが，線分析の結果か ら Fe 濃度は極めて低く，また濃度変化が少ないことが 分る。これに対して上端から $0.6 \mathrm{~cm}$ 下部の $\mathrm{Fe}$ 分布を示 す(3)の写真では Fe が著しく高濃度に濃縮し, 線分析 の結果も極めて高い値を示している。白の表示が $\mathrm{Fe}$ 濃 度が最も高いことを示すが，その割合は上部領域の方に 多く, $\mathrm{Fe}$ が最終凝固領域に大部分偏析し, 濃縮するこ とが示されている。この部分の $\mathrm{Fe}$ の等濃度線を描いた

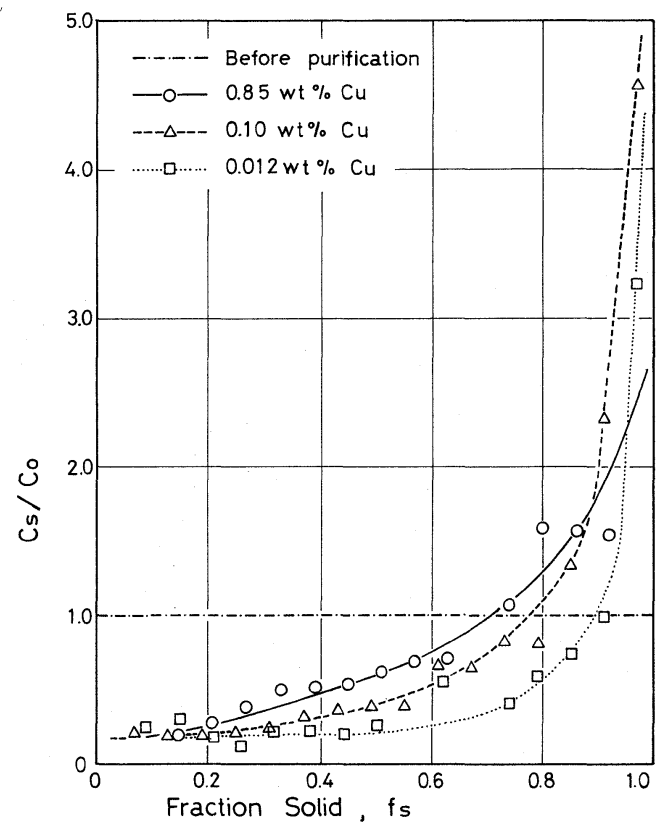

Fig. 11 Effect of $\mathrm{Cu}$ concentration on the purification ratio for the solidification with ultrasonic vibration and mechanical stirring.
のが Fig. 10(2)の写真である。白，赤，青の各等濃度曲 線で $\mathrm{Fe}$ 濃度が表示されており，これらの形状から判断 すると $\mathrm{Fe}$ が大きな粒子として存在し，偏析，濃縮が極 めて大きいことが示唆される。

以上のマッピングアナライザーによる結果は化学分析 による不純物の濃度分布測定結果とよく一致している。

\section{6 初期不純物濃度之精製比の関係}

初期不純物濃度の違いによつて精製の度合が異なるこ とが認められたので，精製比に及ぼす初期不純物濃度の 影響を検討した。 $\mathrm{Al}-\mathrm{Cu}$ 合金, $\mathrm{Al}-\mathrm{Mg}$ 合金打よび $\mathrm{Al}-$ $\mathrm{Fe}$ 合金の結果を Fig. 11 13 亿示す。縦軸に精製比 $\left(C_{s}\right.$ $\left./ C_{0}\right)$ を取り，横軸に固相率 $\left(f_{s}\right)$ をとつて示した。これ らはいずれぬ超音波振動々機械的擋汼を同時に与充た場 合である。これらの結果によれば，いずれの合金でも精 製比は固相率の増加とともに増大し，特に固相率 0.8 以 上では急激に増加する。すなわちいずれの合金でも固相 率0.6以下では不純物が除去され， $\mathrm{Al}$ が精製されている ことが分る。初期不純物濃度が低い合金では $\mathrm{Al}$ 精製の 固相率は増加し, 約0.8程度まで増大する。このように 精製比は初期不純物濃度が低い:ど小さい傾向が認めら れるが， $\mathrm{Al}-1.04 \mathrm{wt} \% \mathrm{Fe}$ 合金を除いて，固相率 0.4 以下 の精製比は初期不純物濃度に依存せず，大約一定值を示 す。例总ば $\mathrm{Al}-\mathrm{Mg}$ 合金試料ではその精製比は 0.5 を示 す。この挙動は $\mathrm{Al}$ の精製に対して超音波振動と機械的

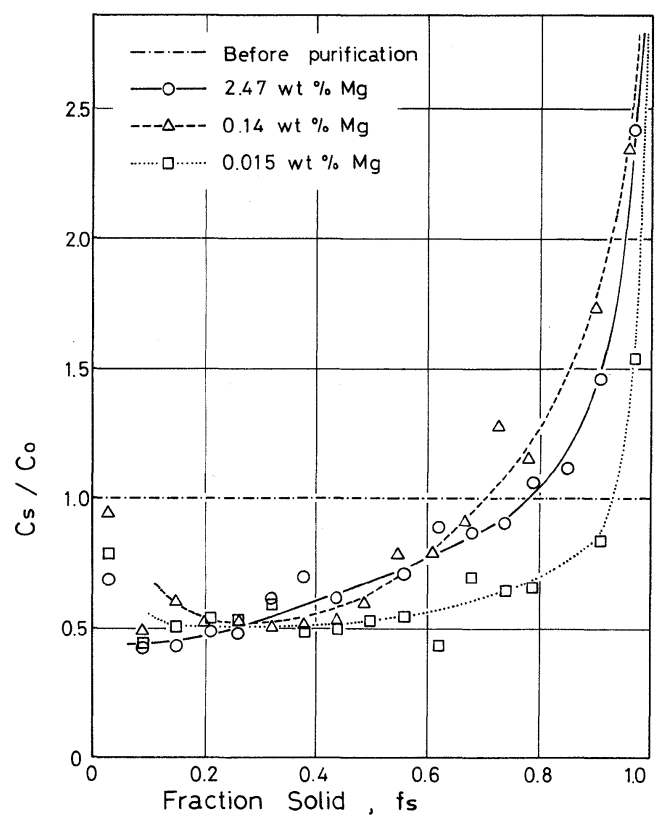

Fig. 12 Effect of $\mathrm{Mg}$ concentration on the purification ratio for the solidification with ultrasonic vibration and mechanical stirring. 


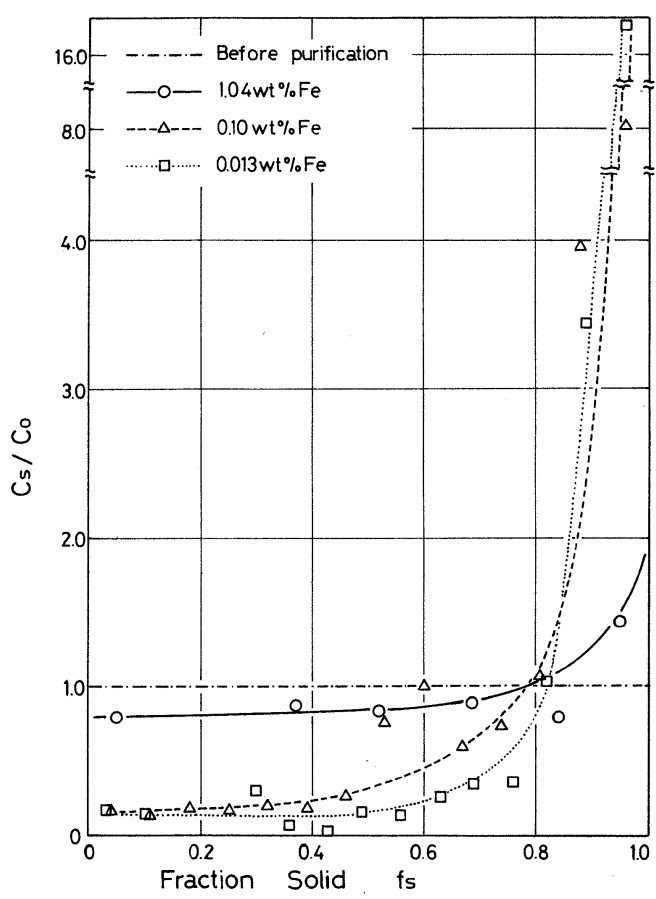

Fig. 13 Effect of $\mathrm{Fe}$ concentration on the purification ratio for the solidification with ultrasonic vibration and mechanical stirring.

撹找が有効に作用していることを示唆している。

\section{5. 考察}

\section{1 凝固界面形態}

各合金の不純物濃度分布が初期濃度により異なる傾向 を示したことは凝固が進行する際の固液界面の形態の相 異によるものと推察される。そこで実験原理で述べた組 成的過冷理論によつて, 各処理条件における凝固界面形 態を検討した。組成的過冷理論は平らな界面の安定性を 推定するもので，その安定条件は(4)式を書き変えて (5) 式のように表される。ここで㠜固速度 $V$ は Table 1 で示 L

$$
G / V \geqq-m \cdot C_{0}(1-k) / k D
$$

た実測值 $R$ から補正計算して求められる。（5)式を用い て凝固の界面形態を推定できるが，計算するに当り， $m, C_{0}, k, D, G$ 抌よび $V$ の值が必要である。これらの值 に実測值および文献值 ${ }^{9)}$ 10) の数値を用い, 平らな界面 の臨界值 $G_{0} / V_{0}$ および実測の $G / V$ を求め, その結果か ら固液界面形態について推定を行つた。得られた結果を Table 2 に示す。この表から分るように初期不純物濃度 が低い合金では平らな界面で凝固が進行すると推定さ れ, 固相から排出された不純物元素は超音波振動と機械 的擋汼の効果により，バルク相へ移動し，精製されやす
Table 2 The critical value of $G / V$ calculated from eq (6) and the interface shape assumed

\begin{tabular}{|c|c|c|c|c|c|c|}
\hline \multirow{2}{*}{ Sample } & \multicolumn{3}{|c|}{$C_{0}(\mathrm{wt} \%)$} & \multirow{2}{*}{\multicolumn{2}{|c|}{ 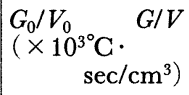 }} & \multirow{2}{*}{$\begin{array}{c}\text { Interface- } \\
\text { shape }\end{array}$} \\
\hline & $\mathrm{Cu}$ & $\mathrm{Mg}$ & $\mathrm{Fe}$ & & & \\
\hline No. 1 & 0.012 & - & - & 4.86 & 167 & Planar \\
\hline No. 2 & 0.012 & - & - & 4.86 & 209 & Planar \\
\hline No. 3 & 0.012 & - & - & 4.86 & 138 & Planar \\
\hline No. 4 & 0.10 & - & - & 40.5 & 186 & Planar \\
\hline No. 5 & 0.10 & - & - & 40.5 & 178 & Planar \\
\hline No. 6 & 0.10 & - & - & 40.5 & 191 & Planar \\
\hline No. 7 & 0.85 & - & - & 344 & 212 & Cellular \\
\hline No. 8 & 0.85 & - & - & 344 & 228 & Cellular \\
\hline No. 9 & 0.85 & - & - & 344 & 218 & Cellular \\
\hline No. 10 & - & 0.015 & - & 1.20 & 136 & Planar \\
\hline No. 11 & - & 0.015 & - & 1.20 & 251 & Planar \\
\hline No. 12 & - & 0.015 & - & 1.20 & 184 & Planar \\
\hline No. 13 & - & 0.14 & - & 11.2 & 192 & Planar \\
\hline No. 14 & - & 0.14 & - & 11.2 & 216 & Planar \\
\hline No. 15 & - & 0.14 & - & 11.2 & 221 & Planar \\
\hline No. 16 & - & 2.47 & - & 197 & 217 & Planar \\
\hline No. 17 & - & 2.47 & - & 197 & 204 & Planar \\
\hline No. 18 & - & 2.47 & - & 197 & 246 & Planar \\
\hline No. 19 & - & - & 0.013 & 23.9 & 230 & Planar \\
\hline No. 20 & - & - & 0.013 & 23.9 & 196 & Planar \\
\hline No. 21 & - & - & 0.013 & 23.9 & 176 & Planar \\
\hline No. 22 & - & - & 0.10 & 298 & 230 & Cellular \\
\hline No. 23 & - & - & 0.10 & 298 & 226 & Cellular \\
\hline No. 24 & - & - & 0.10 & 298 & 191 & Cellular \\
\hline No. 25 & - & - & 1.04 & 5026 & 164 & Dendrite \\
\hline No. 26 & - & - & 1.04 & 5026 & 241 & Dendrite \\
\hline No. 27 & - & - & 1.04 & 5026 & 194 & Dendrite \\
\hline
\end{tabular}

$C_{0}$ : Initial concentration

$G$ : The temperature gradient measured in this study

$V$ : The rate of solidification

$G_{0} / V_{0}$ : The critical value of $G / V$

$G / V$ : The measured value obtained by this study

いものと推察される。一方初期不純物濃度が高い合金で は固液界面で過冷が生じやすくセル状界面で㠜固が進行 し，セル状偏析が起るため，精製度は平らな界面と比べ れば妨げられる。セル状偏析の例は各種 $\mathrm{Al}$ 合金で報告 されており，例えば $\mathrm{Al}-0.09 \mathrm{wt} \% \mathrm{Fe}$ 合金のセル界面で はセル壁のくぼみに存在する $\mathrm{Fe}$ 量は初期濃度の80倍の

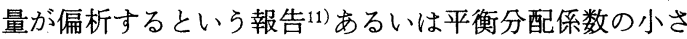
い $\mathrm{Al}-0.5 \mathrm{wt} \% \mathrm{Zn}$ 合金では初期濃度の 5〜 10倍の $\mathrm{Zn}$ の 偏析 ${ }^{12)}$ が認められている。このようにセル状界面で凝固 が進行すると不純物元素がセル間隙に濃縮され, 精製が 妨げられると考えられる。

\section{2 理論精製比一固相率曲線}




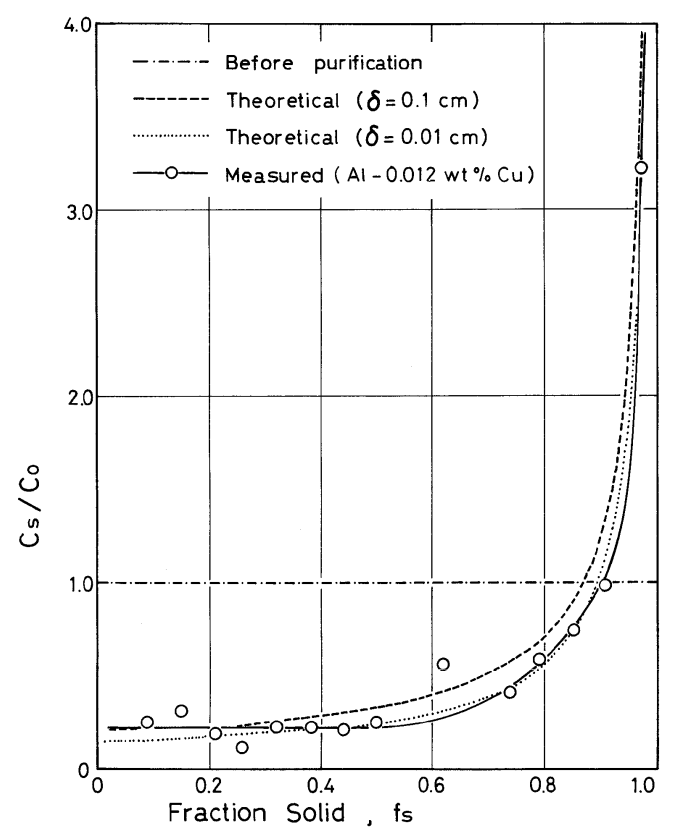

Fig. 14 Comparison between measured and theoretical purification ratio for $\mathrm{Al}-0.012 \mathrm{wt} \% \mathrm{Cu}$ alloy.

平らな平面で㠜固が進行すると推定された合金では原 理の項で述べた液相中で部分的混合がある場合（曲線 3）に対応する濃度分布と同様な挙動を示すはずである。 すなわち(2) 式を変形した $(6)$ 式の精製比 $\left(C_{s} / C_{0}\right)$ 一固相 率 $(f s)$ 曲線においては

$$
C_{s} / C_{0}=k_{e}\left(1-f_{s}\right)^{k_{e}-1}
$$

初期不純物濃度 $C_{0}$ が関与せず，たとえ $k_{e}$ が濃度に左右 される $k$ に依存するとしてもその変化量が非常に小さい ので，凝固が平らな界面で進行するならば，初期不純物 濃度にかかわらず(6)式に対応する精製比一固相率曲線 が得られると推察される。

Fig. 14 およびFig. 15 は平らな界面で凝固が進行し たと推定される超音波振動と機械的擋拌を同時に加えた $\mathrm{Al}-0.012 \mathrm{wt} \% \mathrm{Cu}$ 合金と $\mathrm{Al}-0.1 \mathrm{wt} \% \mathrm{Cu}$ 合金の実験結果 と (3) 式，(6)式によつて与えられる理論曲線とを比較し て示したものである。Fig. 14 では拡散層の厚さ $\delta=$ $0.01 \mathrm{~cm}$ と仮定した場合に理論曲線と実験結果とがよく 対応しており，この合金試料では精製が理想的に行われ たことを示している。また Fig. 15 では固相率0.5付近ま では実験值が理論值とよく一致しているが, 固相率が増 加するにしたがいその差が大きくなる傾向が認められる。

Fig. 16 はセル状界面で凝固が進行したと推定される $\mathrm{Al}-0.85 \mathrm{wt} \% \mathrm{Cu}$ 合金の実験結果と理論曲線とを比較し たもので, 測定值のプロットは理論曲線と対応せず, 精

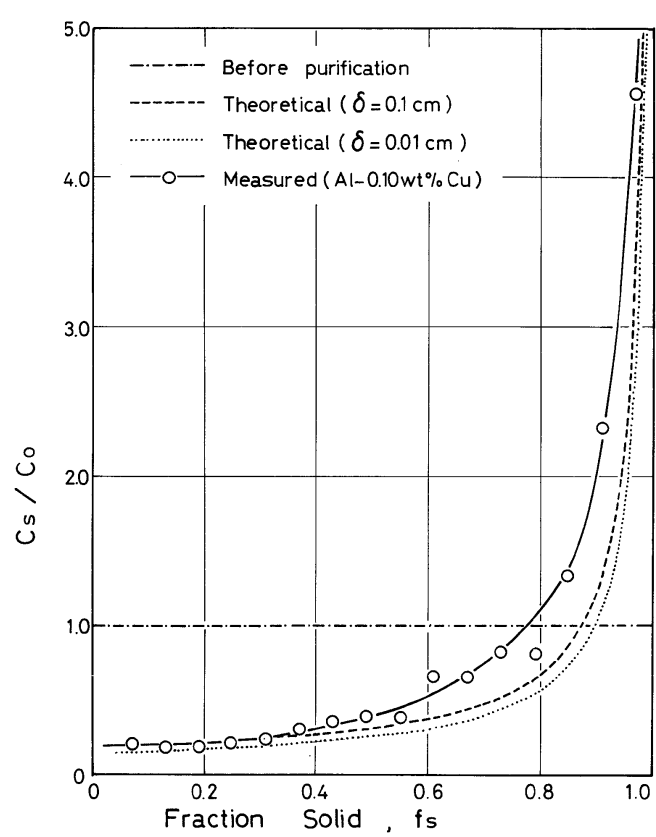

Fig. 15 Comparison between measured and theoretical purification ratio for $\mathrm{Al}-0.10 \mathrm{wt} \% \mathrm{Cu}$ alloy.

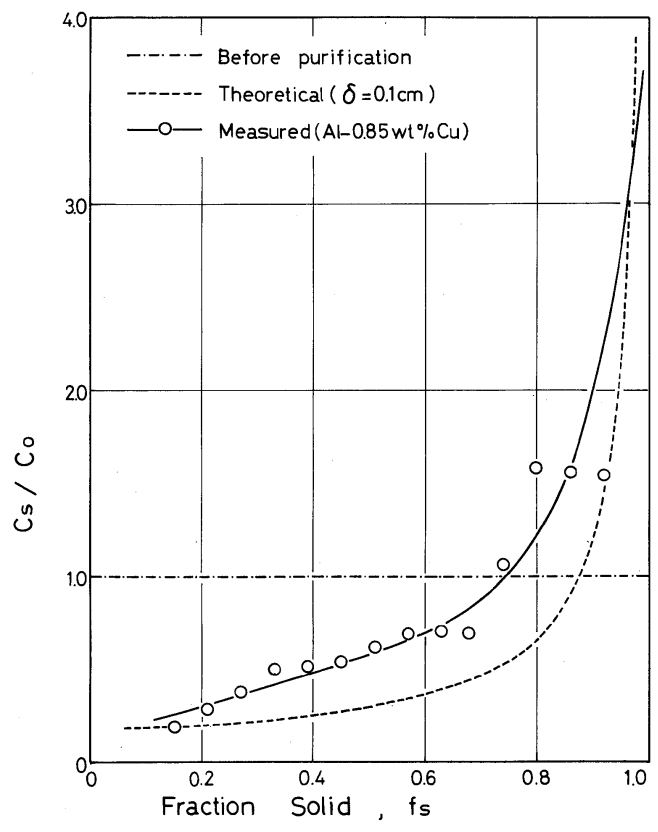

Fig. 16 Comparison between measured and theoretical purification ratio for $\mathrm{Al}-0.85 \mathrm{wt} \% \mathrm{Cu}$ alloy.

製が低下している。また $\mathrm{Al}-\mathrm{Mg}$ 合金および $\mathrm{Al}-\mathrm{Fe}$ 合金 の場合も $\mathrm{Al}-\mathrm{Cu}$ 合金と同様に初期不純物濃度が低い場 合に理論曲線と実測值がよく対応したが，初期濃度が高 
い場合には両者の一致の度合は低下した。以上実験結果 之理論值の対応から，特に不純物濃度が低い合金の場 合, 超音波振動々機械的擋找を同時に加えることは拡散 層の厚さを小さくすると同時に液体の混合をより完全に するので，精製に対して効果的であると考兄られる。

\section{3 超音波振動亡機械的擋拌の効果}

初期不純物濃度が高くセル状界面で凝固が進行したと 推定される $\mathrm{Al}-0.85 \mathrm{wt} \% \mathrm{Cu}$ 合金, $\mathrm{Al}-2.47 \mathrm{wt} \% \mathrm{Mg}$ 合金 および $\mathrm{Al}-1.04 \mathrm{wt} \% \mathrm{Fe}$ 合金の各試料では一方向的凝固 よりも超音波振動のみを加えた方が，超音波振動と機械 的擋拌を同時に加えた場合の方が一層よく精製された。 この実験結果を考慮し, 超音波振動と機械的摚汼の効果 を検討する。超音波の特徵の一つとして強力な音波を発 生することである。特に媒体が液体ならばその作用は大 きく，その強力な音圧によりキャビテーションの発生, 溶質の分散作用が起る。このキャビテーション, 分散作 用の起る周波数範囲は通常 $20 \sim 50 \mathrm{kHz}$ で，本実験では $20 \mathrm{kHz}$ の起音波振動を与えているからこの上らな現象 が固液界面で起ると考学られる。拡散層内で固相から排 出された不純物元素はキャビテーションによる気孔の発 生・消減によつてかき乱され, 圧力のサイクルに対応し て拡散層内をある瞬間は液相近くへ，ある瞬間は固相近 くへと振動を繰り返す。このとき，もし拡散層が薄けれ ば不純物の拡散層外への排出が促進される。そして機械 的擋拌によつて拡散層の厚さが小さくなり，その時超音 波振動が与兄られていれば不純物元素のバルク相への移 動が大きく，よく精製されることになる。このように考 えると初期不純物濃度の高い場合に超音波振動々摚找が 各合金の精製厄効果的であるという実験結果とよく対応 する。な括, 凝固界面形態に対する超音波と擋汼の効果 については新宮らの直接観察の報告13)がある。

\section{6. 結言}

溶融金属を凝固した場合の溶質の偏析現象に着目し， アルミニウム精製の基礎研究として, $\mathrm{Al}-\mathrm{Cu}$ 合金, $\mathrm{Al}-$ $\mathrm{Mg}$ 合金および $\mathrm{Al}-\mathrm{Fe}$ 合金を作製し，これらを一度溶融 した後，処理条件を变えながら一方向的に凝固させ，銅 マグネシウム，鉄の濃度分布を調べ，精製に対する超音 波振動および機械的擋汼の有効性を検討した。得られた 結果を要約すると次のと打りである。
（1）各合金とも初期不純物濃度が異なると，凝固後の不 純物の分布状態も変化し, 精製の度合が異なることが判 明した。またこれらの結果を固液界面の形態を推定でき る組成的過冷理論に基ついてて解析した。

（2）初期不純物濃度の低い合金の精製においては超音波 振動と機械的擋汼を同時に与えることにより，理想的な 精製比一固相率曲線を得ることができた。

（3）初期不純物濃度の高い合金の精製に対する超音波振 動と機械的摚拌の効果は不純物濃度の低い合金の場合よ りも大きかつた。これは凝固がセル状界面で進行して も, 超音波振動と機械的擋拌により, 固液界面が一層混 合状態となり不純物のバルク相への移動が促進されるか らであると考えられる。

\section{謝 辞}

本研究を遂行するに当り有益なご助言を頂いた東北大 学工学部金属工学科山村力博士および佐藤譲博士に対 し, 深く感謝致します。またマッピングアナライザーに よる分析を行つて頂いたセイコー電子工業株式会社伊在 氏に感謝申し上げます。

\section{参 考 文 献}

1）アルミニゥムの現況：日本アルミニウム連盟, テ キスト, 昭和60年 6 月, p. 45.

2) W. G. Pfann: Zone Melting, John Wiley (1958).

3) W. A. Tiller, K. A. Jackson, J. W. Rutter and B. Chalmers: Acta. Met., 1 (1953), 428.

4） B. Chalmars 著, 岡本, 鈴木共訳：金属の凝固, 丸善 (1981), 121.

5）神尾：軽金属, 31 (1981), 136.

6) J. A. Burton, R. C. Primm and W. P. Slichter: J. Chem. Phys., 21 (1953), 1987.

7) W. W. Mullins and R. F. Sekerka: J. Appl. Phys., 35 (1964), 444.

8） 日本工業規格：アルミニウムおよびアルミニウム 合金の原子吸光分析法, H1306-1974.

9）佐藤：日本金属学会会報, 18 (1979), 588 .

10）雄谷：軽金属, 17 (1967), 44 .

11）高橋, 神尾, 小島, グェン・アン・チュン：軽金 属, 21 (1971)， 463.

12）高橋, 神尾, 小島, クェン・アン・チュン：軽金 属, 20 (1970), 611.

13）新宮, 尾崎, 平野, 新井, 大塚：日本金属学会秋 期大会シンポジウム講演集（1979）, p. 169. 